\title{
Agro-morphological Characteristics of Local Upland Rice in Arakan Valley, Cotabato, Philippines
}

\author{
Juliet P. Candog - Bangi \\ College of Agriculture, MSU - Main Campus, \\ Marawi City, Philippines \\ Mary Ann Robelle L. Polido and Vermando M. Aquino \\ PMBPVL, NIMBB, College of Science, University of the Philippines, \\ Diliman, 1101 Quezon City, Philippines
}

\begin{abstract}
Agronomic and morphological characteristics of fourteen (14) local upland rice cultivars of Arakan Valley, Cotabato, Philippines were evaluated to determine desirable traits in improving upland rice production and for future breeding purposes. Traditional upland rice seeds differ in shape, size, colour and aroma. Azucena and Kapalawan have longer grains of 9-12 mm and the smallest grain was from Mal-os of 5.5- $8 \mathrm{~mm}$. Bungulan, Ulipapa, and Magalitok cultivars have medium size grain of about 8-11 mm. Azucena and Bungulan have translucent caryopsis and aromatic. Mubpon had medium grain size and semi-aromatic and Dinorado had aromatic pinkish to purplish caryopsis and medium size grain. Hinumay and Azucena have the tallest height among rice cultivars with 126.5 and $127 \mathrm{~cm}$, respectively. Malundiang got the shortest height of $91 \mathrm{~cm}$. Kawilan got the highest number of tillers with 6.5 and 5 panicles per plant. Malundiang cultivar flowered early at 65-70 days while Azucena and Kawilan have late flowering of more than 90 days after planting. Magalitok had the longest panicle with $31.06 \mathrm{~cm}$ and the shortest panicle was measured from Malundiang with 16.63 $\mathrm{cm}$. Ulipapa had the highest 1,000-grain weight of $28.54 \mathrm{~g}$ while Manisi got the lowest grain weight of $15.33 \mathrm{~g}$ only. The result of the study showed variation in the agro-morphological characteristics of the indigenous upland rice. Bungulan, Ulipapa, Malundiang, Mubpon, Sinulid and Kawilan have potential agronomic characteristics in improving upland rice production in the IP community. Dinorado, Hinumay, and Azucena have been planted by the local farmers for its desirable grain characteristics and aroma.
\end{abstract}

Keywords: agro-morphological, indigenous upland rice, Arakan Valley, aromatic.

\section{Introduction}

Agro-morphological study deals on the plant growth structure characterization (morphological) and yield component of an important crop like upland rice. The characteristics include visual expression of growth structure largely influenced by the environment, cultural practices and gene-environment interaction (Bruschi et al., 2003). Morphological study in rice is important to determine the desirable characteristics of certain rice species including its potential yield (Seetharam et al. 2009). Accordingly, the practice of agro-morphological characterization is the easiest method among the formal and standardized approaches of measuring crop genetic diversity (Watson and Eyzaguire, 2002). Modern rice plant breeders are concerned with diversity at the molecular level but local farmers are most interested in the visible characteristics and yielding ability of rice.

Cotabato province is one of the rice bowls in the Southern Philippines due to favorable climate, fewer typhoons and vast track of rich soils despite of the uncertain political stability. The place is inhabited by the Tri-people, the "Moro" (Muslims), "Lumad" (indigenous people or IPs), and the Christian migrants or settlers. Much indigenous upland rice in Arakan Valley, Cotabato 
were kept and grown by the Manobo (Menuvu) communities for generations and considered as insignia of their ethnic culture and beliefs. They identified desirable characteristics of upland rice like grain quality, aroma, and apparently its recuperative effect. It can resist adverse condition like low rainfall and lower temperature in the undulating landscape (Arakan-LGU, 2001).

Most of the "Lumad" (primarily Menuvu tribe) lived in the mountainous areas intertwining upland rice in their daily existence. The local government unit of Arakan Valley, Cotabato through the Municipal Agriculture Officer (MAO) instigated to retrieve and conserve the remaining indigenous upland rice particularly those with desirable characteristics. The conservation work started in the early 1990s by a non-government organization, Southeast Asia Regional Initiatives for Community Empowerment (SEARICE) and formerly known as CONSERVE. There is a risk and higher possibility for upland rice genetic erosion and extinction due to continuous landscape transformation and massive conversion of the production areas into high-valued plantation crops like rubber, oil palm and banana. It is necessary to save the remaining traditional upland rice proven to resist environmental pressures with good edibility. This is the best way to secure the food sources of the tribal farmers and safeguard their rights to keep the commodity from generation to generations.

Increasing agricultural productivity is one of the government priorities to meet the food demands of the country's population. Aside from increasing production, the indigenous peoples (IP) and other local farmers are helped out in their food needs. The study was conducted to evaluate the agro-morphological characteristics of local upland rice kept and grown by the IPs for several years in Arakan Valley Complex. In this aspect, it would help improve rice production in the countryside specifically in the indigenous community and identify potential local upland rice cultivars for future breeding purposes.

\section{Materials and Methods}

\section{Description of the collection site}

Traditional upland rice cultivars were collected from different tribal communities in Arakan Valley Complex composed of the municipalities of President Roxas, Antipas, Arakan, and the eastern part of Matalam, situated in the second district of Cotabato Province, Philippines (Figure1). The place is bounded by Bukidnon province in the north and Davao del Sur in the east. The collection areas are known as the major upland rice producer in Central Mindanao since the early 1960s and 1970s with marked landscape and varied terrain to small hills that gradually rise to mountains. Arakan is predominantly inhabited by Manobo (Menuvu) tribes and with the presence of other ethnic groups like Bagobo and Tiduray (Arakan-LGU, 2001).
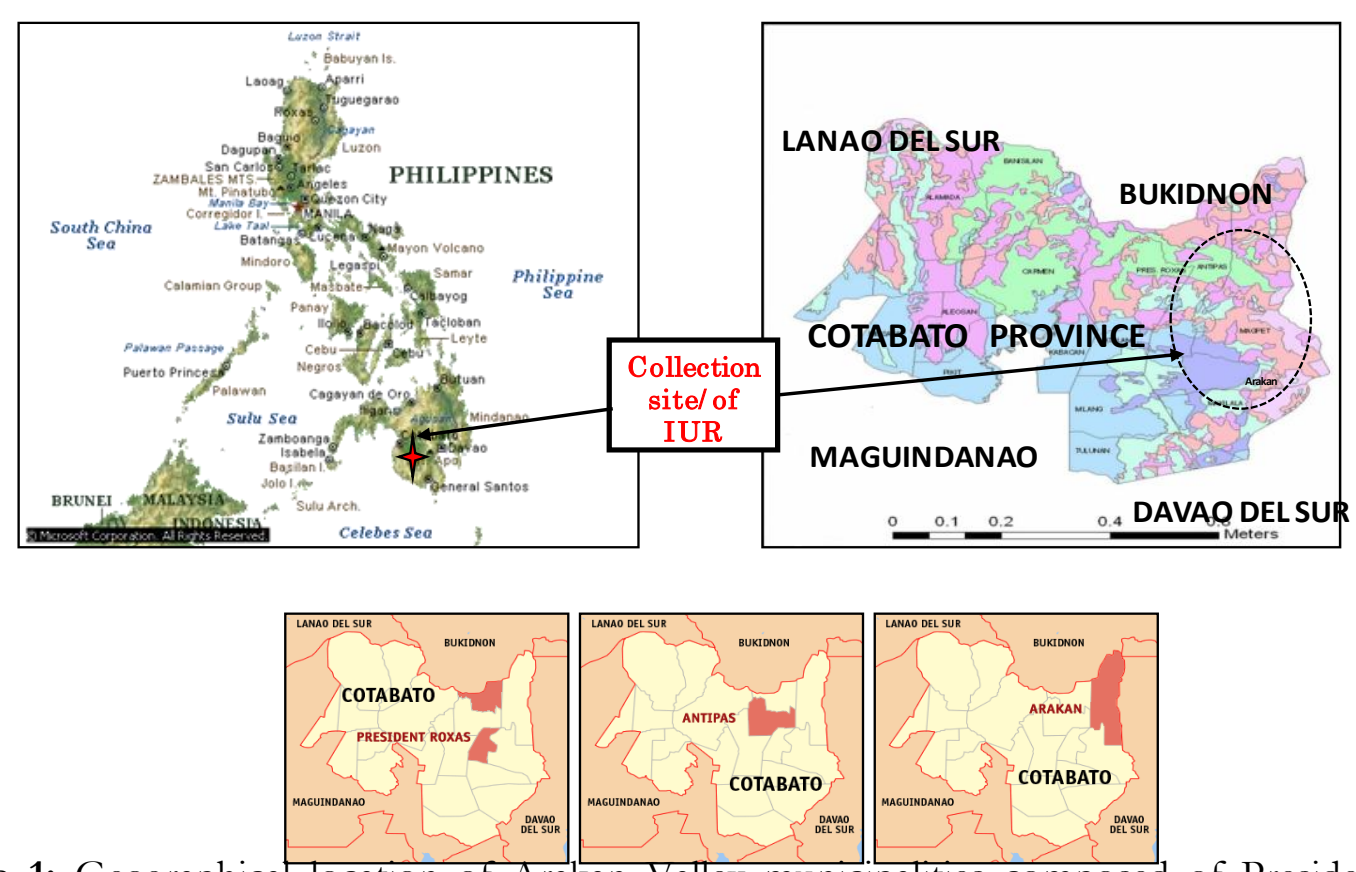

Figure 1: Geographical location of Arakan Valley municipalities composed of President Roxas, Antipas, Matalam East and Arakan, Cotabato as collection site of indigenous upland rice (IUR). 


\section{Collection of plant materials}

Ethno-botanical principles were followed in the collection of local upland rice grains kept by the farmers. A prior informed consent was secured from the Manobo tribal council leaders or "datu" (chieftains) in Arakan Valley, Cotabato, Philippines and from the local government unit (LGU) represented by the Municipal Agriculture Officer (MAO) in the seed collection. Permissions were also sought through certification from non-government organization, Southeast Asia Regional Initiatives for Community Empowerment (SEARICE) (formerly CONSERVE) which pioneered in the collection and conservation of traditional upland rice in the study area.

Fourteen (14) traditional upland rice cultivars were collected in the identified production areas (Table 1). Local names were used in the identification and the names of the farmer/s or contributors including the place of collection were recorded separately as necessary information. Certifications were secured from the Philippine Rice Research Institute (PhilRice) and International Rice Research Institute (IRRI) to validate related agronomic study on the collected local upland rice cultivars.

Table 1: Traditional upland rice collected in different geographical location in Arakan Valley, Cotabato, Philippines.

\begin{tabular}{ll}
\hline Traditional & Names \\
\hline Dinorado* & Arakan, Cotabato \\
Azucena* & Arakan, Cotabato \\
Bungulan & Kulaman Valley, Salat, President Roxas, \\
Mal-os & Matalam and Arakan, Cotabato \\
Magalitok & Guinto, President Roxas, Cotabato \\
Kapalawan & Arakan, Cotabato \\
Mubpon & President Roxas, Cotabato \\
Manisi & Salat, President Roxas, Cotabato \\
Kawilan & President Roxas, Matalam and Arakan, Cotabato \\
Malundiang & President Roxas and Arakan, Cotabato \\
Sinulid & Arakan, Cotabato \\
Ulipapa & Arakan, Cotabato \\
Dabao & President Roxas, Matalam and Arakan, Cotabato \\
Hinumay & Arakan, Cotabato \\
\hline *Upland rice cultivars locally grown by the Manobo tribal farmers. \\
logical characteristics of local upland rice
\end{tabular}

Agro-morphological characteristics of local upland rice

The collected upland rice grains were morphologically characterized while other seeds were directly sown in the pots and boxes/plots filled with garden soil added with organic materials under greenhouse condition. The agronomic parameters gathered were plant height $(\mathrm{cm})$, number of tillers, number of days to flower and maturity, number of panicle per plant, length of panicle and weight of 1,000 grains. Data collections were done at two weeks interval except for 1,000 grain weight (g) which was taken after harvesting. These agro-morphological traits are measured based from the methods used by Sohrabi et al. (2012).

\section{Data Analysis}

In the agronomic characterization, one plant was maintained for every pot -10 inches in diameter until harvesting replicated 4 times and 10 to 12 plants per $1 \mathrm{~m}^{2}$ box/plot. All plants were considered as samples in the quantitative characteristics. Data taken were analyzed using STAR software (from IRRI) in the analysis of variance (ANOVA) and means are compared using HSD test.

\section{Results and Discussion}

\section{Morphological description of local upland rice grains}

The morphological characteristics of local upland rice grains differ among cultivars (Table 2). Most of the grains vary in size, shape, plumpness, hulls (pericarp) and caryopsis color with aroma or scent. The grain size of upland rice ranged from 5-12 mm, width and hull thickness vary also among local upland rice while some seeds have longer awn while others have short to awn-less characteristics (Figure 2). Azucena and Bungulan have similarities in seed color with light yellow to yellowish brown, oblong and elongated shape, $10-12 \mathrm{~mm}$ seed length and aromatic. The caryopsis is medium 
to long and translucent. Seeds of Mubpon and Ulipapa have round to oval shape but differ in hull color, texture and aroma. The former has thicker purple hulls and semi-aromatic while the latter is non-aromatic with golden brown hulls with shades of light yellow. Magalitok upland rice seeds have unique shape, slim and elongated (like thin stick) with short awn and black tip. Kapalawan has long grain with short to long awn, yellow to light brown yellow color hulls and semi-aromatic reddish caryopsis (Table 2 and Figure 2). Other upland rice seeds like Sinulid and Kawilan have similar morphological characteristics. They have comparable medium size of $7-9.5 \mathrm{~mm}$ length, oblong shape, light yellow lemma and palea, and translucent non-aromatic caryopsis. Mal-os has the smallest seed with light yellow to brown yellow hulls, awnless, translucent caryopsis and non-aromatic (Table 2 and Figure 2).

The observed morphological characteristics of the upland rice grains were mostly comparable with the description of Japonica and Javanica type of rice (Rabara et al., 2014; Zang et al., 1992; IRRI, 1975; Chang et al., 1972). The Japonica grains are short, roundish, awnless to longawned and have variety of colors (white, brown, black, purple and red), while those grains that are long, broad, thick hulled and awned or awn-less are the Javanica type of upland rice (Rabara et al., 2014; IRRI, 1975; Chang et al., 1972). The study of Semwal et al. (2014) and Phunngam et al. (2017) have similar findings in the local upland rice variation in grain characteristics like size, shape, hull and endosperm color, presence of awn and some are aromatic.

Wang et al. (2012) considered the importance of grain size and form which are main components of yield and quality. These traits have been used as the basis of selection in the first domestication of cereals. Vua Xiongsiyee and Chanakan Prom-U-Thai (2016) mentioned rice grain characteristics as source of the primary information on the genetic variation of different rice varieties in the local germplasm. The variations in the grain structure of upland rice cultivars were proven in the genetic diversity analysis done by Bangi and Aquino (2014). There are upland rice grains that are morphologically similar but it showed a very low (nil) genetic similarity when it was analyzed using SSR markers. The findings were observable with Azucena and Bungulan, between Mubpon and Malundiang and other upland rice cultivars.

Table 2: Grain characteristics of local upland rice cultivars collected in Arakan Valley Complex, Cotabato, Philippines

\begin{tabular}{|c|c|c|c|c|c|}
\hline \multirow{3}{*}{$\begin{array}{l}\text { Traditional } \\
\text { Upland Rice }\end{array}$} & \multicolumn{5}{|c|}{ Seed morphological characteristics } \\
\hline & \multirow{2}{*}{$\begin{array}{l}\text { Seed size } \\
(\mathrm{mm})\end{array}$} & \multirow[t]{2}{*}{ Shape } & \multicolumn{2}{|l|}{ Color } & \multirow[t]{2}{*}{ Other features } \\
\hline & & & $\begin{array}{l}\text { Hulls } \\
\text { (lemma } \\
\text { palea) }\end{array}$ & caryopsis & \\
\hline 1. Azucena & $\begin{array}{l}\text { 10-12 (long } \\
\text { grain) }\end{array}$ & $\begin{array}{l}\text { elongated } \\
\text { oblong }\end{array}$ & $\begin{array}{l}\text { light yellow to } \\
\text { yellowish } \\
\text { brown }\end{array}$ & $\begin{array}{l}\text { white } \\
\text { luminous }\end{array}$ & $\begin{array}{lr}\text { short awn }(0.5- \\
2 \mathrm{~mm}) & \text { to } \\
\text { awnless, aromatic }\end{array}$ \\
\hline 2. Dinorado & $\begin{array}{l}\text { 6-8 (small } \\
\text { to medium) }\end{array}$ & semi-round & $\begin{array}{l}\text { brown to } \\
\text { darker brown }\end{array}$ & $\begin{array}{lr}\text { lighter } & \text { pink } \\
\text { and } & \text { darker } \\
\text { red } & \end{array}$ & $\begin{array}{l}\text { short awn to } \\
\text { awnless; } \\
\text { aromatic }\end{array}$ \\
\hline 3. Mal-os & $\begin{array}{l}5.5-8 \text { (small } \\
\text { to medium) }\end{array}$ & oblong & $\begin{array}{l}\text { light yellow to } \\
\text { brown yellow }\end{array}$ & $\begin{array}{l}\text { white } \\
\text { luminous }\end{array}$ & $\begin{array}{l}\text { awnless ; non- } \\
\text { aromatic }\end{array}$ \\
\hline 4. Malundiang & $\begin{array}{l}7 \quad-8.5 \\
\text { (medium) }\end{array}$ & $\begin{array}{l}\text { plump } \\
\text { round or } \\
\text { oval }\end{array}$ & Yellow brown & $\begin{array}{l}\text { white } \\
\text { luminous }\end{array}$ & $\begin{array}{l}\text { with awn \& } \\
\text { others awnless; } \\
\text { tip of grain dark } \\
\text { brown color, } \\
\text { non-aromatic }\end{array}$ \\
\hline 5. Dabao & $\begin{array}{l}7-9 \\
\text { (medium) }\end{array}$ & $\begin{array}{l}\text { plump } \\
\text { semi-round }\end{array}$ & $\begin{array}{l}\text { light yellow or } \\
\text { brown color }\end{array}$ & $\begin{array}{l}\text { white } \\
\text { luminous }\end{array}$ & $\begin{array}{l}\text { dark brown awn } \\
\text { about } 0.5 \mathrm{~mm} \text {; } \\
\text { non-aromatic }\end{array}$ \\
\hline 6. Kawilan & $\begin{array}{l}\text { 7-9 } \\
\text { (medium) }\end{array}$ & oblong & light yellow & $\begin{array}{l}\text { white } \\
\text { luminous }\end{array}$ & $\begin{array}{ll}\text { short awn } & (0.5- \\
1 \mathrm{~mm}) ; & \text { non- } \\
\text { aromatic } & \\
\end{array}$ \\
\hline 7. Mubpon & $7-8.5$ & round & yellow & white & short awn; semi- \\
\hline
\end{tabular}




\begin{tabular}{|c|c|c|c|c|c|}
\hline & (medium) & Oval & brown & luminous & aromatic \\
\hline 8. Ulipapa & $\begin{array}{l}\text { 8-11(med.- } \\
\text { long) }\end{array}$ & $\begin{array}{l}\text { round or } \\
\text { oval }\end{array}$ & $\begin{array}{l}\text { golden brown } \\
\text { with shades of } \\
\text { light yellow }\end{array}$ & $\begin{array}{l}\text { white } \\
\text { luminous }\end{array}$ & $\begin{array}{l}\text { awnless; non- } \\
\text { aromatic }\end{array}$ \\
\hline 9. Magalitok & $\begin{array}{l}\text { 8-11(med.- } \\
\text { long) }\end{array}$ & $\begin{array}{l}\text { slim- } \\
\text { elongated }\end{array}$ & $\begin{array}{l}\text { variegated } \\
\text { light yellow } \\
\text { brown-dark } \\
\text { brown }\end{array}$ & $\begin{array}{l}\text { white } \\
\text { luminous }\end{array}$ & $\begin{array}{l}\text { short awn and } \\
\text { brown-black tip; } \\
\text { non-aromatic }\end{array}$ \\
\hline 10. Bungulan & $\begin{array}{l}\text { 8-11(med.- } \\
\text { long) }\end{array}$ & $\begin{array}{l}\text { oblong, } \\
\text { semi- } \\
\text { elongated }\end{array}$ & $\begin{array}{l}\text { dark brown to } \\
\text { golden brown }\end{array}$ & $\begin{array}{l}\text { pinkish to } \\
\text { luminous } \\
\text { /white grain }\end{array}$ & $\begin{array}{l}\text { yellowish brown } \\
\text { shades at the tip } \\
\text { and side of grain, } \\
\text { aromatic }\end{array}$ \\
\hline 11. Manisi & $\begin{array}{l}7-8 \\
\text { (medium) }\end{array}$ & $\begin{array}{l}\text { plump, } \\
\text { oblong }\end{array}$ & $\begin{array}{l}\text { light brown } \\
\text { with shades of } \\
\text { dark brown }\end{array}$ & $\begin{array}{l}\text { white } \\
\text { luminous } \\
\text { grain }\end{array}$ & $\begin{array}{l}\text { short dark brown } \\
\text { awn; } \\
\text { non-aromatic }\end{array}$ \\
\hline 12. Sinulid & $\begin{array}{l}7-9.5 \\
\text { (medium) }\end{array}$ & oblong & $\begin{array}{l}\text { light yellow } \\
\text { with brown to } \\
\text { dark brown } \\
\text { tip }\end{array}$ & $\begin{array}{l}\text { white/ } \\
\text { luminous }\end{array}$ & $\begin{array}{l}\text { Short to long awn } \\
\text {; non-aromatic }\end{array}$ \\
\hline 13. Kapalawan & $\begin{array}{l}\text { 9-12(long } \\
\text { grain) }\end{array}$ & oblong & $\begin{array}{l}\text { yellow to light } \\
\text { brown yellow }\end{array}$ & red grain & $\begin{array}{l}\text { short to long } \\
\text { awn }(1-2 \mathrm{~mm}) ; \\
\text { semi-aromatic }\end{array}$ \\
\hline 14. Hinumay & $\begin{array}{l}7-9.5 \\
\text { (medium) }\end{array}$ & $\begin{array}{l}\text { semi-round } \\
\text { or oval }\end{array}$ & $\begin{array}{l}\text { yellowish } \\
\text { brown to light } \\
\text { yellow brown }\end{array}$ & $\begin{array}{l}\text { Mixture } \\
\text { luminous } \\
\text { /white and } \\
\text { red grains }\end{array}$ & $\begin{array}{l}\text { very short awn } \\
0.3 \text { to } 1 \mathrm{~mm} \\
\text { (others awnless); } \\
\text { non-aromatic }\end{array}$ \\
\hline
\end{tabular}

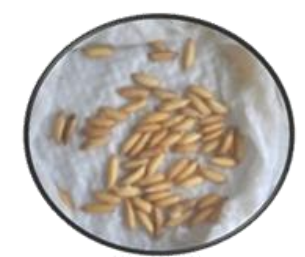

Azucena

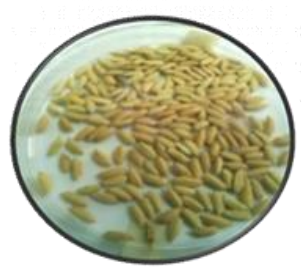

Hinumay

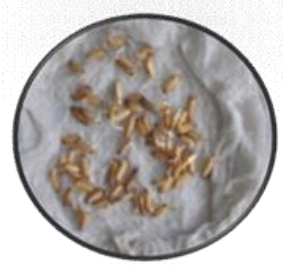

Manisi

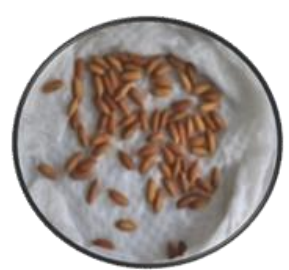

Dinorado

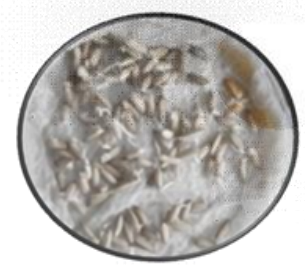

Kawilan

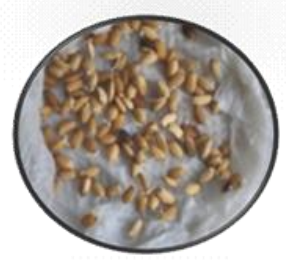

Mubpon

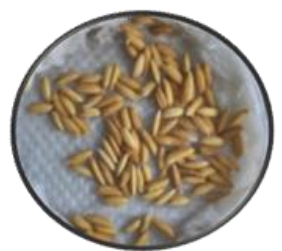

Bungulan

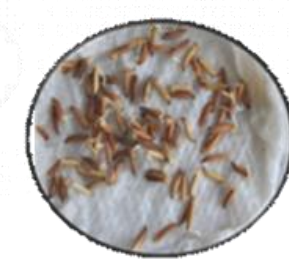

Magalitok

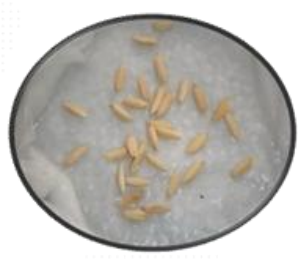

Sinulid

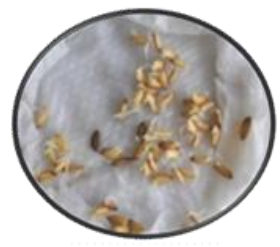

Dabao

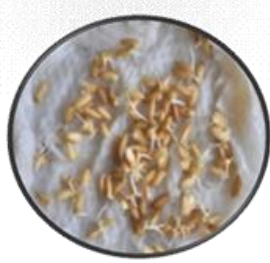

Mal-os

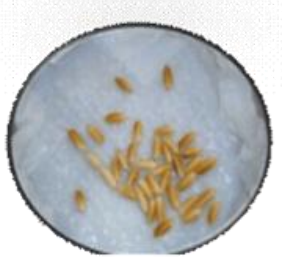

Ulipapa

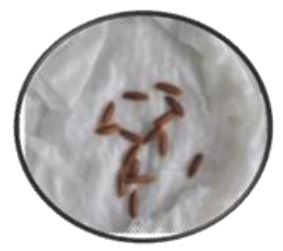

Kapalawan

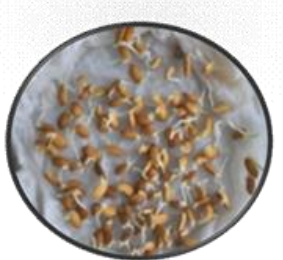

Malundiang

Figure 2. Traditional upland rice cultivars commonly planted in Arakan Valley, Cotabato, Philippines.

\section{Agronomic characteristics of local upland rice}

The agronomic characteristics of the local upland rice showed differences in height, number of tillers, days to flower, panicle numbers and length, and grain weight (Table 3). Hinumay had the 
tallest height of $127.00 \mathrm{~cm}$ on the 14th week but did not vary with Azucena with $126.50 \mathrm{~cm}$. Magalitok had $116.50 \mathrm{~cm}$ height but statistically comparable with Manisi, Sinulid, Ulipapa, Mubpon, Mal-os, Dabao and Bungulan upland rice cultivars (Table 3). Malundiang had the shortest plant height of $91 \mathrm{~cm}$ but did not vary with Kawilan and Dinorado upland rice (Table 3 and Figure 3). Plant height of the local upland rice increased exponentially during vegetative stage and slowed down during the reproductive stage (booting to flowering) (Figure 3).

Table 3: Agronomic characteristics of traditional upland rice cultivars in Arakan Valley, Cotabato, Philippines under greenhouse condition

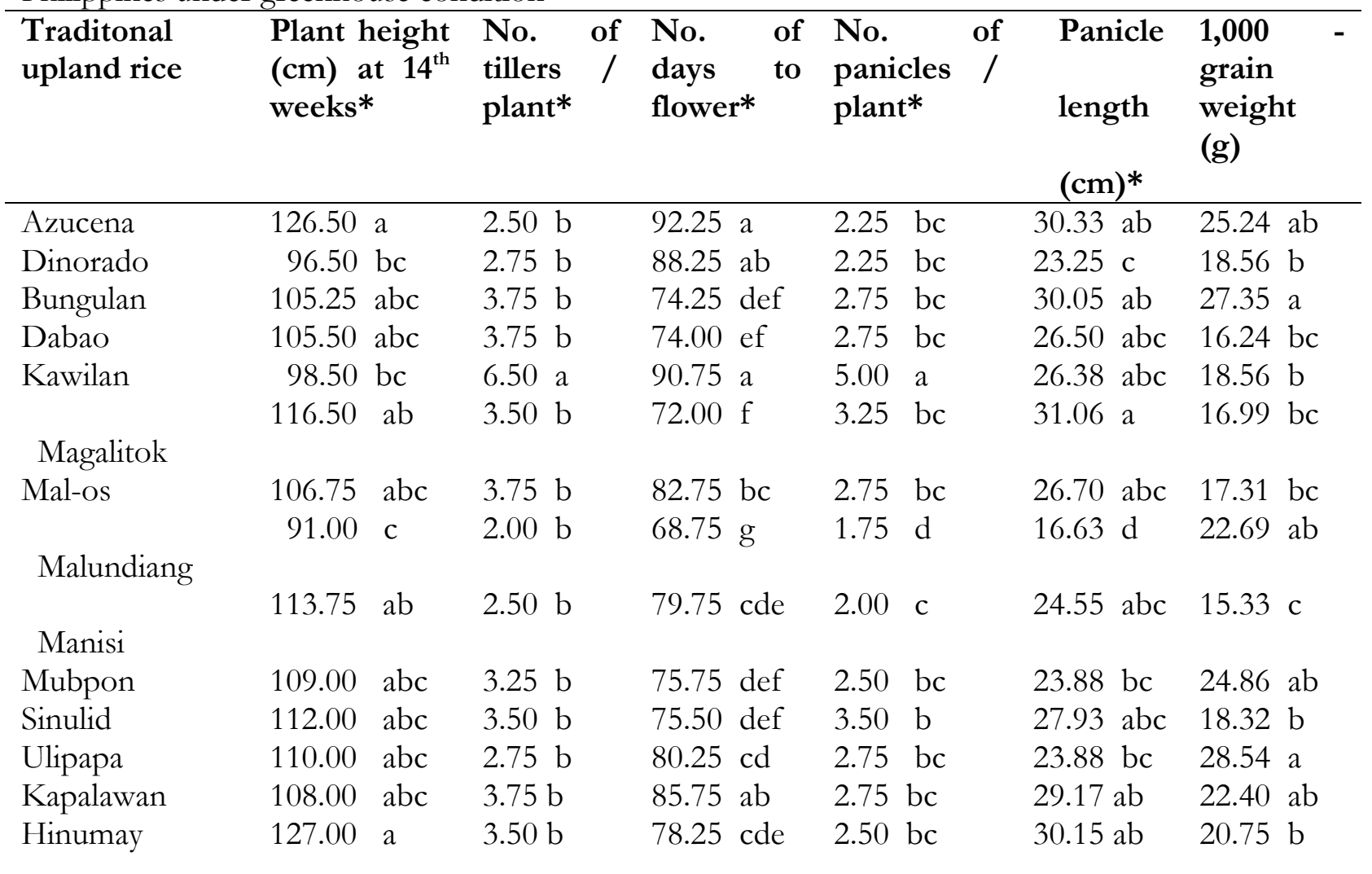

*All means (ave.of 4 reps) with the same letter/s in a column are not significantly different at 1\% level by HSDe Test.

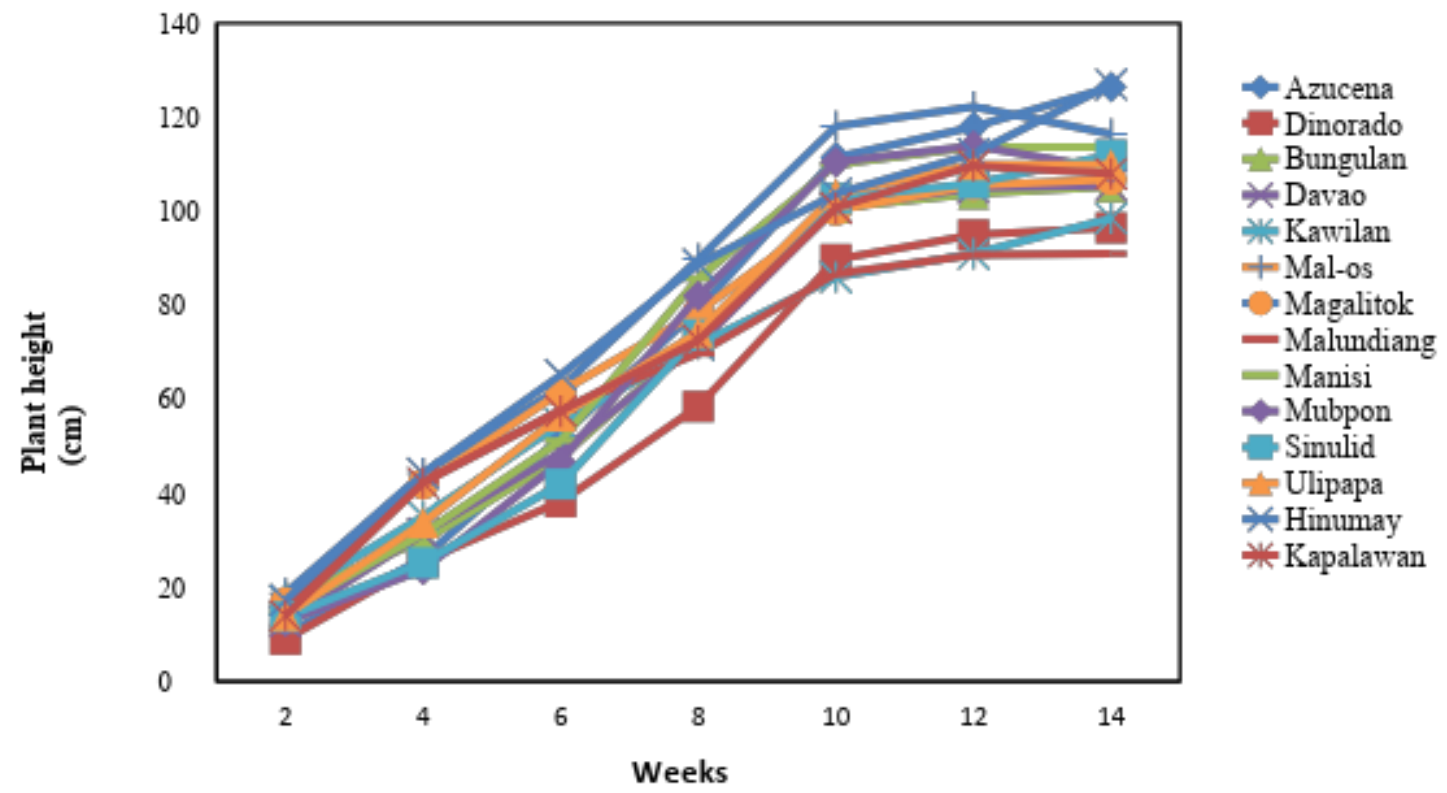

Figure 3. Average plant height $(\mathrm{cm})$ of local upland rice cultivars in Arakan Valley Complex, Cotabato, Philippines under greenhouse condition .

The description on the phenotypic structure specifically the plant height of traditional Philippine rice supported the findings of the study (Rabara et al., 2014; Caldo et al., 1996; IRRI, 1975; Chang et al., 
1972). Upland rice cultivars were found to have tall stature, thick long sturdy stem (culm), longer erectophile and droopy leaves with wide leaf area (broad) than lowland rice. These morphological characteristics were apparent during the growing period of upland rice cultivars although the data presented was plant height only. These characteristics were observable on Bungulan, Sinulid, Ulipapa and Dinorado upland rice which have narrow to medium leaf area, droopy to semierectophile leaves and with long stiff culms. The study of Chang and Vergara (1972) and Schlosser et al. (2000) positively identified traditional upland rice cultivars to have long culms and droopy leaves while other cultivars have narrower leaves. These phenotypic characteristics like erectophile leaves, sturdy stem and culm length were considered important in developing new type of rice plant that affect yield component according to the study of Rabara et al. (2014) and Caldo et al. (1996).

Medium to tall stature upland rice are breed specifically for upland condition or selected locally on the basis of performance under poor moisture conditions (Salazar, 1993). Upland rice cultivars usually of tall stature are prone to lodging. Rabara et al (2014) emphasized the importance of local rice varieties that are cultivated by farmers. Accordingly, it is the main sources of germplasm for breeding new rice varieties since they have traits potentially adaptable to various abiotic and biotic stresses. Characterization of the germplasms is vital in rice improvement and gives valuable information in the new rice varieties.

Upland rice Kawilan produced the highest number of tillers of 6.5 while other cultivars produced 2 to 4 tillers per plant (Figure 4). Upland rice have low number of tillers produced per plant compared to lowland irrigated rice varieties (Rabara et al., 2014; IRRI, 1975; Chang and Vergara, 1975; Chang et al., 1972). Tiller production is an indicator of the yielding capability of upland rice hence, greater number of tillers would likely to produce greater number of panicles during reproductive stage (Rabara et al., 2014; Caldo et al., 1996; IRRI, 1975; Chang et al., 1972).

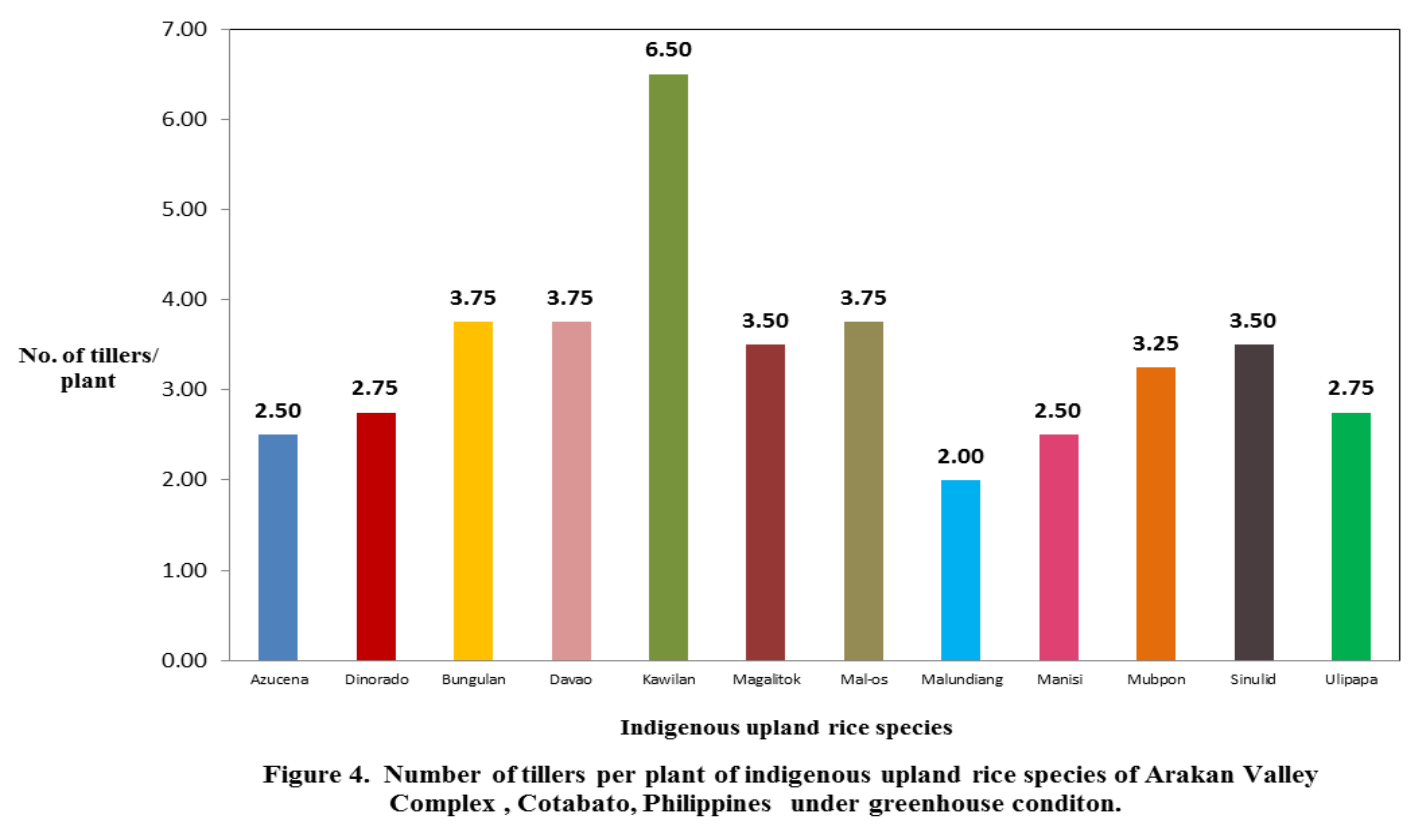

Reproductive stage of upland rice started on the 9th and 10th weeks as indicated by booting followed by panicle initiation and flowering period. Malundiang upland rice flowered early at about 69 days after sowing. Azucena and Kawilan have longer period to flower at about 93 and 91 days, respectively. The flowering period of Azucena and Kawilan did not vary much with Dinorado with 88.25 days (Table 3). Magalitok upland rice flowered at 72 days (next to Malundiang), and Dabao, Bungulan, Mubpon, Sinulid and Manisi rice cultivars flowered at $73-75$ days. The upland rice Mal-os and Ulipapa did not differ in the flowering days with 80.25 (Table 3). Accordingly, the flowering of upland rice is relative to the vegetative growth of the plants. Long profuse tillering period and continued growth able to delay the flowering of the plants while short vegetative growth leads to early reproductive stage (IRRI, 1975; Chang et al., 1972; Chang and Vergara, 1975).

The number of rice panicles per plant is shown in Table 3. Kawilan upland rice had the highest number of 5 panicles per plant while the least number of panicles counted were from Manisi 
and Malundiang cultivars with 2 and 1.75 panicles per plant, respectively (Table 3). The rest of the upland rice cultivars have panicles ranging from 2- 5 per plant. .The result of the study showed upland rice produced very minimal number of panicles compared to lowland irrigated rice varieties. This result is related to the tillers produced per plant as it is potential for panicle formation (Rabara et al. 2014; Zang et al, 1992; IRRI, 1975; Chang et al, 1972). The length of panicle is one of the yield components of rice coupled with the number of grains per panicle. Table 3 shows the variability of upland rice cultivars in terms of panicle length. Magalitok upland rice got the longest panicle of $31.06 \mathrm{~cm}$ and followed by Azucena and Bungulan upland rice with 30.33 and $30.05 \mathrm{~cm}$, respectively. The shortest panicle was measured from Malundiang with $16.63 \mathrm{~cm}$. The upland rice Dabao, Kawilan, Mal-os and Sinulid were found to have a comparable panicle length. In like manner, the Dinorado, Manisi, Mubpon and Ulipapa upland rice cultivars were almost of similar panicle length (Table 3). The study of Rabara et al. (2014), Zang et al (1992), IRRI (1975), Chang et al (1972) and Caldo et al. (1996) found out variations in the different yield components of Philippine upland rice varieties. The study of Sohrabi et al. (2012) confirmed that most traits such as plant height, yield of plant, panicle length, number of panicles, and days to flowering are associated among each other, which suggested that utilization of these traits could help in the selection of cultivars to improve upland rice production.

In terms of 1,000 grain weight, Ulipapa got the highest grain weight of $28.54 \mathrm{~g}$ but did not differ with Bungulan statistically with $27.35 \mathrm{~g}$ (Table 2). The upland rice Azucena, Mubpon, Kapalawan and Malundiang have grain weight of 25.24 g, 24.86 g, $22.4 \mathrm{~g}$ and 22.69 g, respectively but it did not vary among cultivars. The grain weight of upland rice Dinorado, Kawilan, Sinulid and Hinumay were heavier than the grain weight of Dabao, Magalitok and Mal-os. The lowest 1,000 grain weight was measured from Manisi with $15.33 \mathrm{~g}$ (Table 2). The differences in grain weight among upland rice cultivars were due to the seed size and shape. The rice cultivars with long grains and round or oval shape are anticipated to have higher yield potential than the grains with smaller size and slim shape (Table 2). Upland rice with smaller grains were likely to have lower yield based on the findings of the study of Wu et al. (2011), Rabara et al. (2014, IRRI (1975), Chang et al. (1972) and Chang \& Vergara (1972).

\section{Conclusion}

The local upland rice cultivars vary in grain size and shape. Some grains were round or oval while others have oblong contour. Azucena, Kapalawan, and Bungulan have longer (9-12 mm) translucent caryopsis (endosperm) and aromatic. Mubpon had medium grain size and semi-aromatic while Dinorado had aromatic pinkish to purplish caryopsis and medium size grain. Bungulan, Ulipapa, and Magalitok cultivars have medium size grain of about 8-11 mm. Azucena, Dinorado and Bungulan have been planted for several decades by the local farmers due to desirable grain traits like longer to medium grains, oblong and aromatic.

Most of the upland rice were medium to tall, produced few tillers and panicles. Hinumay and Azucena were the tallest among rice cultivars with plant height of 126.5 and $127 \mathrm{~cm}$, respectively. Kawilan got the highest number of tillers with 6.5 and 5 panicles per plant. Malundiang cultivar flowered early at 65-70 days while Azucena and Kawilan have late flowering of more than 90 days after planting. Magalitok had the longest panicle with $31.06 \mathrm{~cm}$ and the shortest panicle was measured from Malundiang with $16.63 \mathrm{~cm}$. Ulipapa had the highest 1,000-grain weight of $28.54 \mathrm{~g}$ while Manisi got the lowest grain weight of $15.33 \mathrm{~g}$ only. The result in grain weight shows that Malundiang and Ulipapa have high yield potential, a good characteristics of upland rice. Bungulan, Mubpon, Sinulid and Mal-os have desirable agronomic characteristics based from the result of this study. The phenotypic variations of traditional upland rice (for both grains and plant structure) indicate species diversity in the locality. Besides, Bangi and Aquino (2014) made prior genetic analysis of the said upland rice cultivars which further prove the distinctions among local cultivars. With the findings of this study, the local community must safeguard the remaining upland rice cultivars that are found potential for improving production and the genetic traits necessary for upland rice breeding programs. 


\section{References}

ARAKAN - Local Government Unit. (2001-2004). Local Poverty Alleviation Plan - C.Y. 2001-2004, Arakan, Cotabato, Philippines.

Bangi, J. C., \& Aquino, V. M. (2014). Genetic Diversity Analysis of Traditional Upland Rice Cultivars in Arakan Valley Complex, Cotabato, Phils. Using SSR Markers. The Asian International Journal of Life Sciences, 23(2), 537-547.

Bruschi, P., Vendramin, G. G., Bussotti, F., \& Grossoni, P. (2003). Morphological and molecular diversity among Italian populations of Quercus petraea (Fagaceae). Analysis of Botany, 91(1), 707-716.

Caldo, R., Sebastian, L., \& Hernandez, J. (1996). Morphology-based genetic diversity analysis of ancestral lines of Philippine rice cultivars. Philippine Journal of Crop Sciences, 21, 86-92.

Chang, T. T., Loresto, G. C., \& Tagumpay, O. (1972). Agronomic and growth characteristics of upland and lowland rice varieties. In Rice Breeding, International Rice Research Institute, Los Banos, Philippines, 645-651.

Chang, T. T., \& Vergara, B. S. (1972). Ecological and genetic information on adaptability and yielding ability in tropical varieties. In International Rice Research Institute (ed) Rice breeding. International Rice Research Institute, Manila,Philippines, 431.

International Rice Research Institute (IRRI). (1975). Major Research in Upland Rice. Los Baños, Laguna, Philippines, 160-183, 1-71.

International Rice Research Institute (IRRI). (1993-1995). IRRI Rice Almanac. Los Baños, Laguna, Philippines, 142.

International Rice Research Institute (IRRI). (1994). Preparing the World's Rice Bowl for the Next Century. In Filling the world's rice bowl. IRRI 1993-1994. Los Baños, Laguna, Philippines, 5-8.

Kafiriti, E. M., Dondeyne, S., Msomba, S., Deckers, J. A., \& Raes, D. (2003). Variations in agronomic characteristics of irrigated rice varieties: lessons from participatory trials in South Eastern Tanzania. Food, Agriculture \& Environment, 1(2), 273-277.

Nascimento, W. F., da-Silva. E. F., \& Veasey, E. A. (2011). Agro-morphological characterization of upland rice accessions. Science Agriculture (Piracicaba, Brazil), 68(6), 652-660.

Phunngam, P., Pathumrangsan, N., Khambai, N., Tongjun, J., \& Arunyawat, U. (2017). The Variation of Indigenous Upland Rice Landraces in Ratchaburi, Thailand Based on Seed Morphology and DNA Sequencing. Journal of Advanced Agricultural Technologies, 4(1), 48-52.

Rabara, R. C., Ferrer, M. C., Diaz, C. L., Newingham, M. C. V., \& Romero, G. O. (2014). Phenotypic Diversity of Farmers' Traditional Rice Varieties in the Philippines. Agronomy, 4(1), 217-241, doi:10.3390/agronomy4020217.

Salazar, A. (1993). A study on the plant genetic resources, diversity and seed supply system of Bohol Island, Philippines. SEARICE, Diliman, Quezon City.

Seetharam, K., Thirumeni, S., \& Paramasivam, K. (2009) Estimation of genetic diversity in rice (Oryza sativa L.) genotypes using SSR markers and morphological characters. African Journal of Biotechnology, 8(10), 2050-2059.

Semwal, D. P., Pandey, A., Bhandari, D. C., Dhariwal, O. P. \& Sharma, S. K. (2014). Variability study in seed morphology and uses of indigenous rice landraces (Oryza sativa L.) collected from West Bengal, India. Australian Journal of Crop Science, 8(3), 460-467.

Schlosser, I., Kranz, J., \& Bonman, J. M. (2000). Morphological Classification of Traditional Philippine Upland Rice Cultivars in Upland Nurseries Using Cluster Analysis Methods for Recommendation, Breeding and Selection Purposes. Journal of Agronomy and Crop Science, 184, 165-171.

Sohrabi, M., Rafii, M. Y., Hanafi, M. M., SitiNorAkmar, A. \& Latif, M. A. (2012). Genetic diversity of upland rice germplasm in Malaysia based on quantitative traits. Scientific World Journal, 2012, 1-9. doi: 10.1100/2012/416291.

Thanh, N. D., Zheng, H.G., Dong, N. V., Trinh, L. N., Ali, M. L. \& Nguyen, H. T. (1999). Genetic variation in root morphology and microsatellite DNA loci in upland rice (Oryza sativa L.) from Vietnam. Euphytica, 105(1), 43-51.

Xiongsiyee, V., \& Prom-U-Thai, C. (2016). Variation in Grain Morphology of Upland Rice Varieties from Luang Prabang Province, Lao PDR. IJERD - International Journal of Environmental and Rural Development, 7(2), 63-69.

Wang, S., Wu, K., Yuan, Q., Liu, X., Liu, Z., Lin, X., Zeng, R., Zhu, H., Dong, G., Qian, Q., Zhang, G., \& $\mathrm{Fu}, \mathrm{X}$. (2012). Control of grain size, shape and quality by OsSPL16 in rice. Nature Genetics, 44, 950954. doi:10.1038/ng.2327

Watson, J. W., \& Eyzaguirre, P. B. (2002). Proceedings of the second International Home Gardens Workshop. 17-19th July, 2001. Witzenhausen Fed. Rep Germany, IPGRI, Rome.

Wu, L. L., Liu, Z. L., Wang, J. M., Zhou, C. Y., \& Chen, K.M. (2011). Morphological, anatomical and physiological characteristics involved in development of the large culm trait in rice. Australian Journal of Crop Sciences, 5(1), 1356-1363.

Zang, Q. F., Maroof, M. A. S., Lu, T. Y., \& Shen, B. S. (1992). Genetic diversity and differentiation of indica and japonica rice detected by RFLP analysis. Theory of Applied Genetics, 83(1), 495-499. 
Appendix Figure 1: Vegetative stage of selected local upland rice of Arakan Valley, Cotabato, Philippines
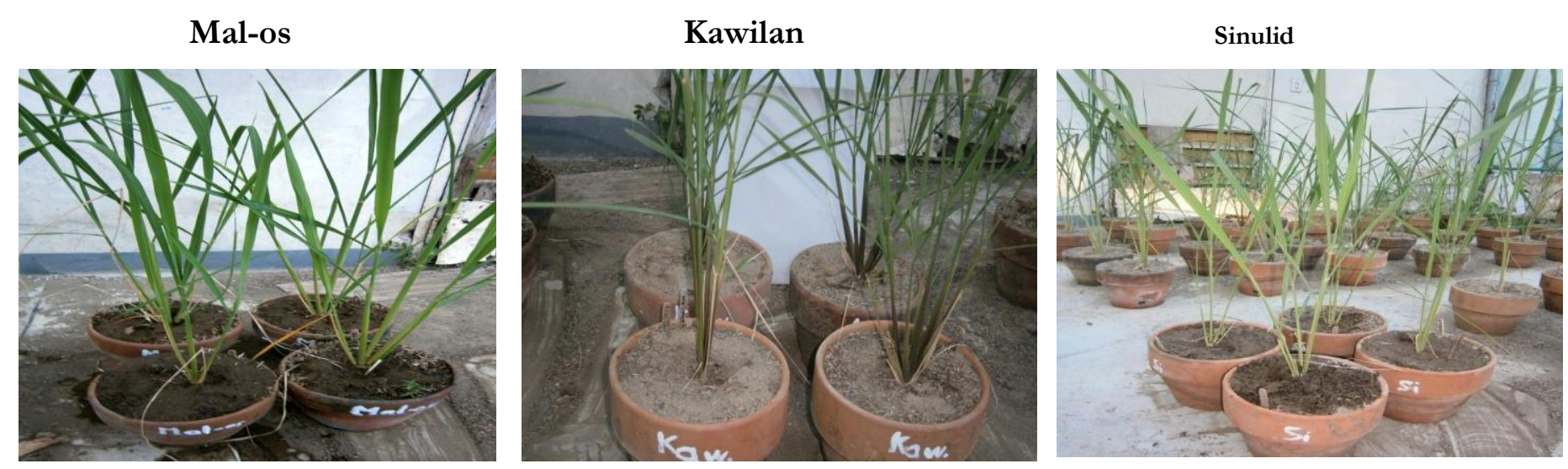

Appendix Figure 2: Selected indigenous upland rice at reproductive stage and ripening period.

Ulipapa
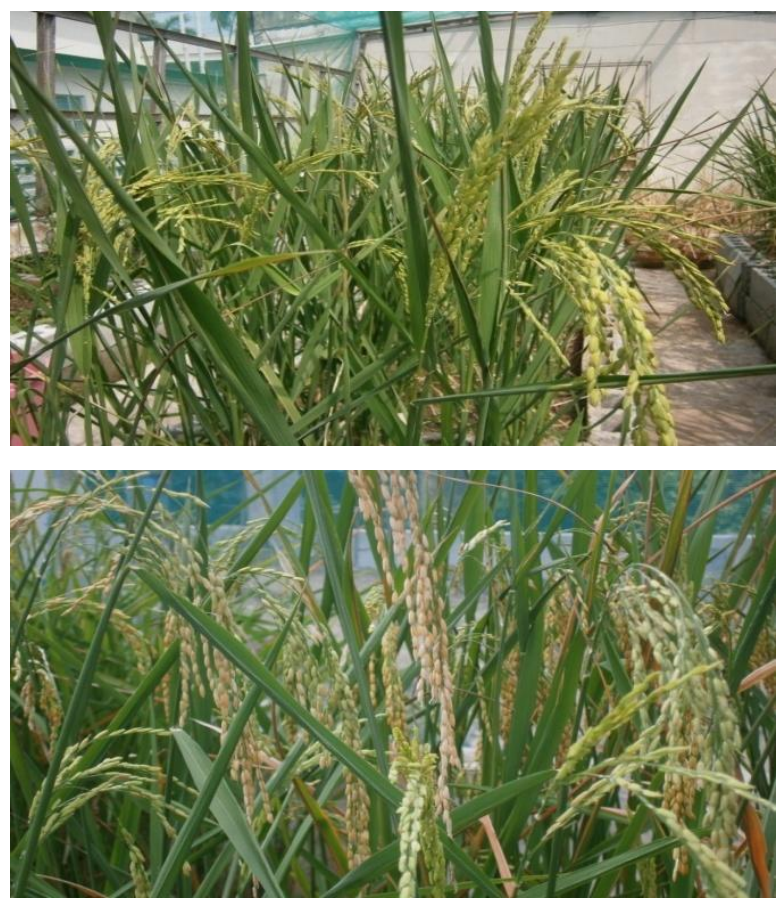

Kawilan
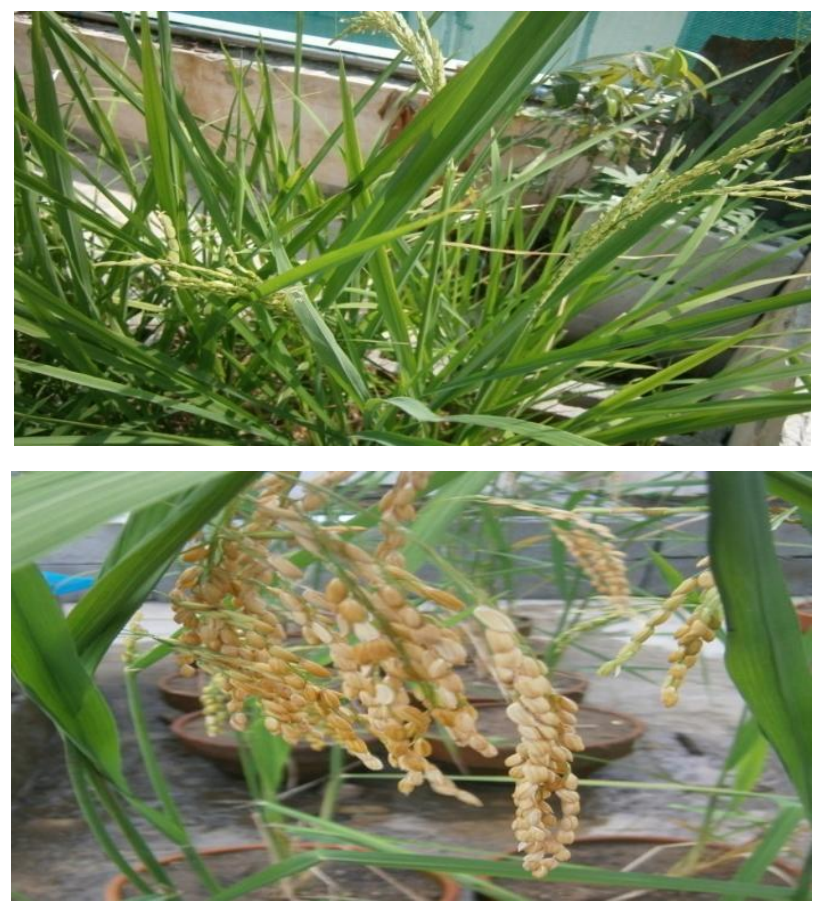

Mubpon

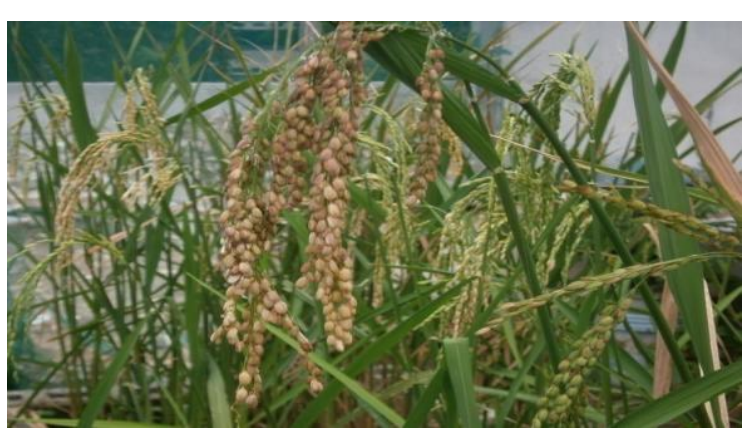

Magalitok

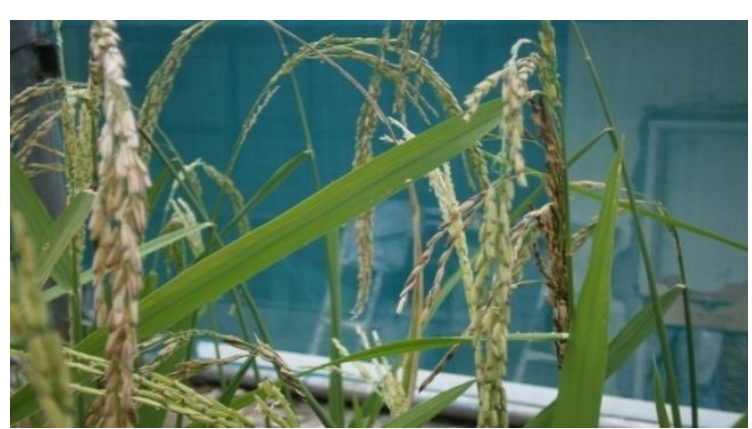


Malundiang

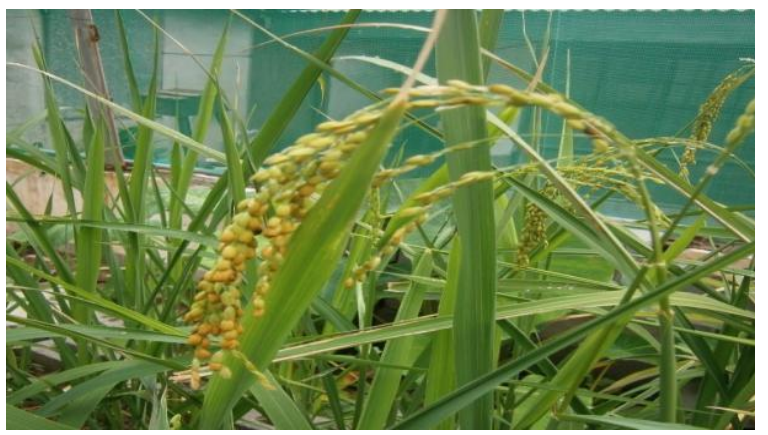

Dabao

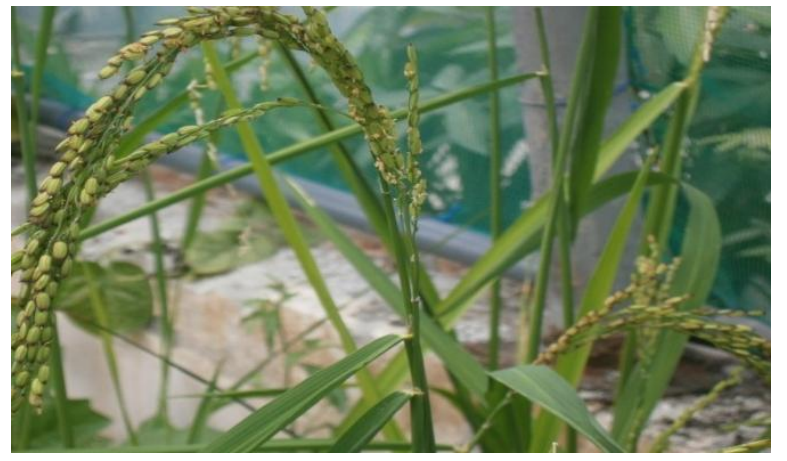

Hinumay

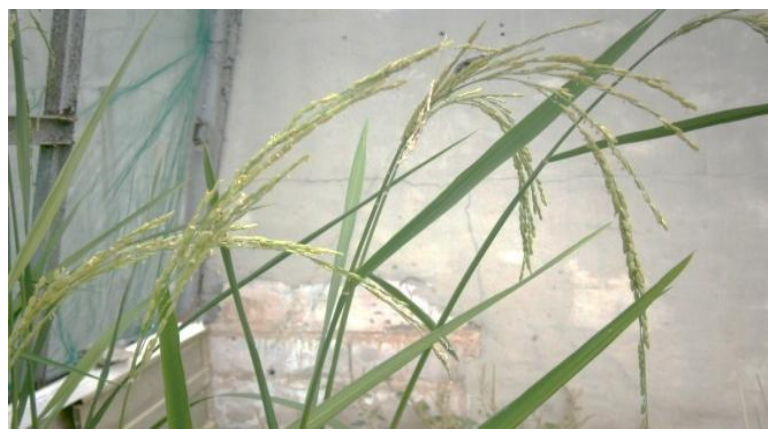

Kapalawan

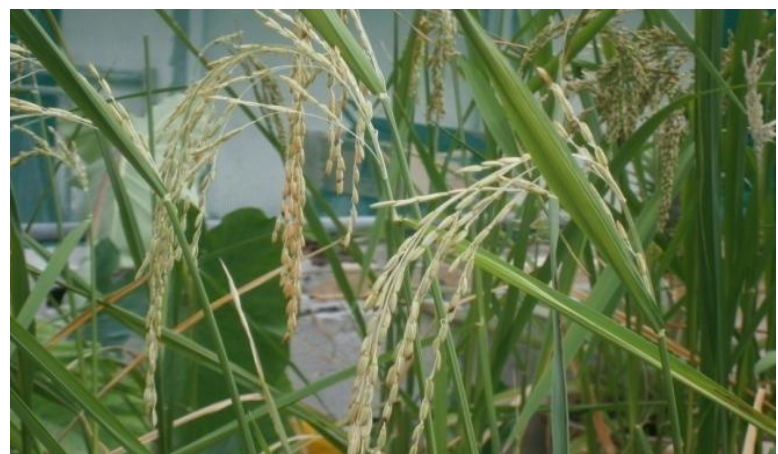

Appendix Figure 3: Rice panicles of traditional upland rice cultivars of Arakan Valley, Cotabato, Phils.

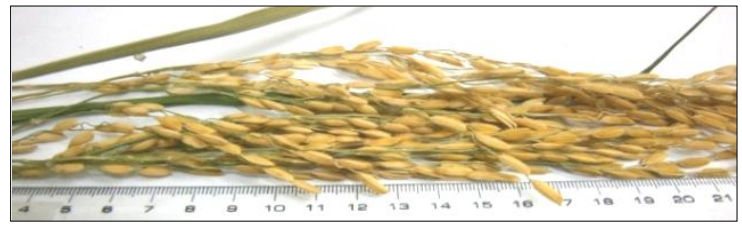

Bungulan Mubpon

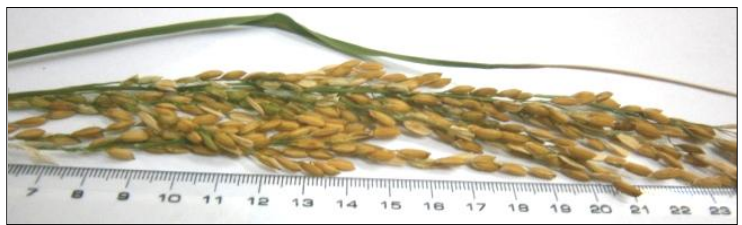

Dinorado

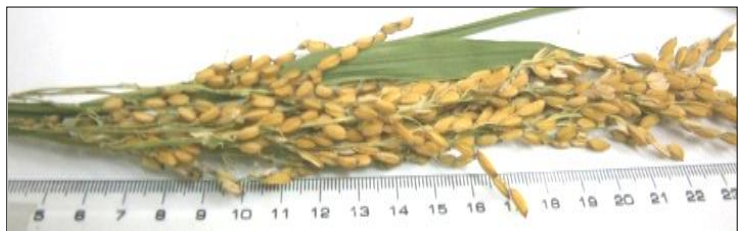

Dabao Manisi

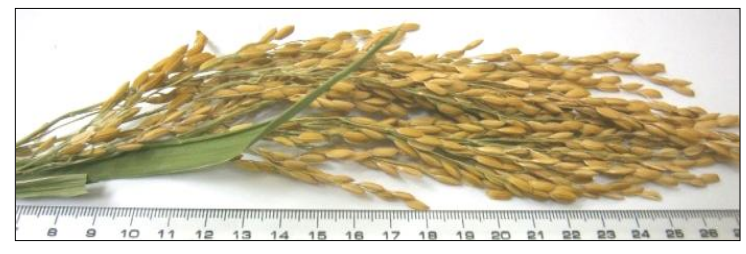

Ulipapa
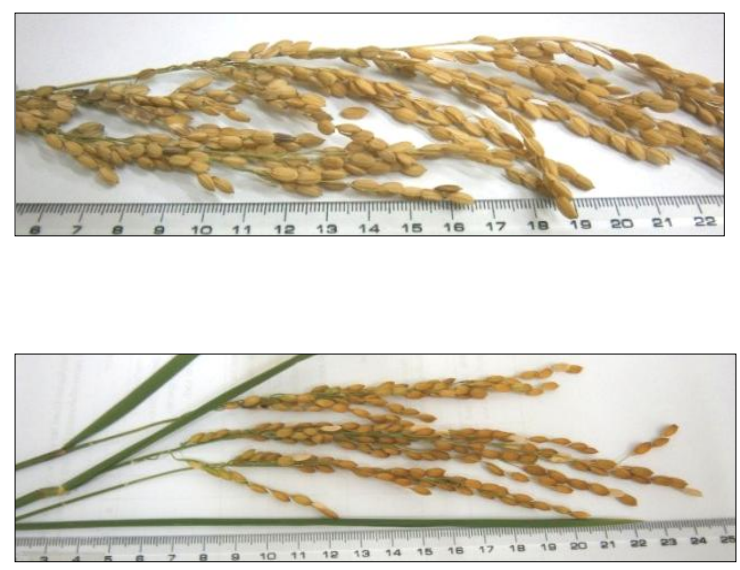

Malundiang
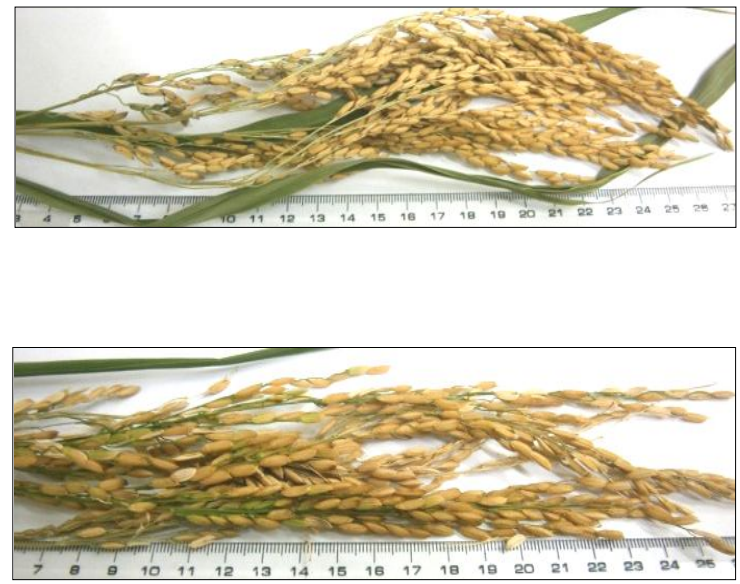

Sinulid 


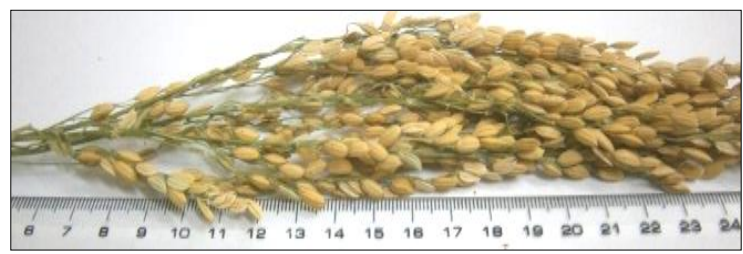

Mal-os

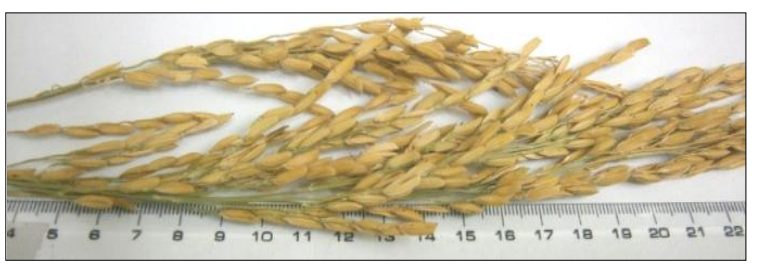

Azucena

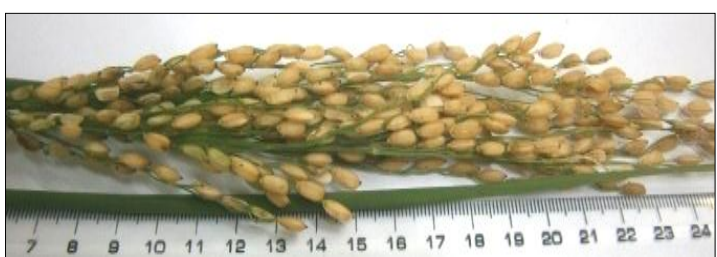

Kawilan

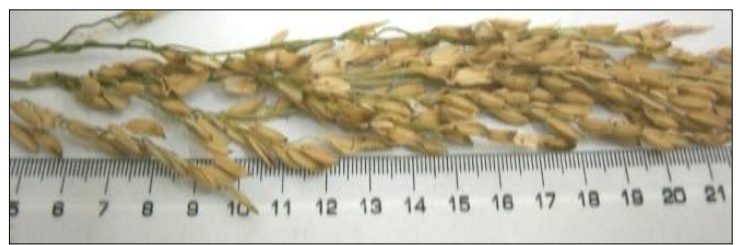

Magalitok

\section{Acknowledgement}

This research was made possible due to the financial assistance of the Department of Agriculture Bureau of Agricultural Research (DA-BAR) and the technical training of the University of the Philippines - Natural Sciences Research Institute in the Post Doctoral and Senior Scientist Research Fellowship granted to the main author. The primary researcher is highly indebted to the local government unit (LGU) of Arakan Valley Complex, Cotabato, Philippines specifically the Municipal Agriculture Officer (MAO) and the upland rice research team, the Manobo tribal leaders of Arakan Valley Complex (MALUPA), and the SEARICE for providing information and sharing indigenous upland rice seeds collected from the study area.

\section{The Authors}

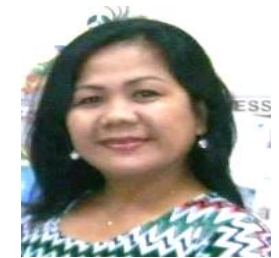

Dr. Juliet C. Bangi graduated MS Agronomy (1997) and Ph D in Soil Science (2007) from UP Los Banos, and a postdoctoral research fellow of the UP Diliman - Natural Sciences Research Institute, Diliman, Quezon City. She is an Associate Prof. of the Plant Science Department, College of Agriculture, Mindanao State University-Main Campus, Marawi City, Philippines.

Mary Ann Robelle L. Polido, Research Assistant, Plant Molecular Biology and Plant Virology Laboratory, National Institute of Molecular Biology and Biotechnology, College of Science, University of the Philippines Diliman, 1101 Quezon City, Philippines.

Dr. Vermando M. Aquino, Head of Laboratory and Asso. Professor, Plant Molecular Biology and Plant Virology Laboratory, National Institute of Molecular Biology and Biotechnology, College of Science, University of the Philippines Diliman, 1101 Quezon City, Philippines. 